\title{
Impact of fine-dust air burden on the mass balance of a high mountain glacier: a case study of the Chongce ice cap, west Kunlun Shan, China
}

\author{
HAN Jiankang, ${ }^{1}$ Masayoshi NAKAWO, ${ }^{2}$ Kumiko GOTO-AZUMA, ${ }^{3}$ LU Chao ${ }^{4}$ \\ ${ }^{1}$ Research Institute of Environment and Resources, Hunan Normal University, Changsha 410081, Hunan, China \\ E-mail: hjk@hunnu.edu.cn \\ ${ }^{2}$ Research Institute for Humanity and Nature, Takashima-cho 335, Kyoto 602-0878, Japan \\ ${ }^{3}$ National Institute of Polar Research, Kaga, Itabashi-ku, Tokyo 173-8515, Japan \\ ${ }^{4}$ Qinghai Normal University, Xining 810008, Qinghai, China
}

\begin{abstract}
The coherent variations of annual snow accumulation rate and dust deposition over 60 years are recorded in an ice core drilled at $6530 \mathrm{~m}$ a.s.l. on the Chongce ice cap, located in the west Kunlun Shan, south of the Taklimakan desert in China. These records were investigated in the context both of the dust transport pathways from the source region and of climatic changes in this arid environment. The factors relating the dust transport from the source to sink area were taken into account to ascertain the integration of these factors on the precipitation-forming process at high elevations. Results indicate that: (1) dust is predominant among aerosols in precipitation at high altitude; (2) the dust aerosol population may be more instrumental than the vapor supply in the formation of precipitation at such altitudes; (3) compared to low-elevation glaciers, snow accumulation on high mountain glaciers seems to be more sensitive to changes in the concentration of air-burden dust particulates, which are closely related to the climatic variations around the desert region; and (4) under the current climate conditions surrounding the desert region, the decreasing trend in snow accumulation, in concert with the decrease in dust deposition that has occurred over the past several decades, might continue. This effect on snow accumulation at high altitudes may explain one of the elements potentially responsible for the longer-term glacial variation, i.e. the glacial retreat that has lasted for decades in central Asia.
\end{abstract}

\section{INTRODUCTION}

The retreat of mountain glaciers in central Asia has attracted considerable attention in recent years. A monitoring station has been maintained since 1959 on Ürümqi glacier No. 1, located at the headwaters of the Ürümqi river in the Tien Shan, China. Currently the glacier is $2.4 \mathrm{~km}$ long and covers an area of $1.95 \mathrm{~km}^{2}$, but over the observation period (up to 2000) it has undergone a vertical net loss of $\sim 80 \mathrm{~cm}$, the terminus has retreated by $171.0 \mathrm{~m}$ and the total area has shrunk by $0.217 \mathrm{~km}^{2}$ (Jiao and others, 2004). The glaciers in the southern Qinghai-Tibetan Plateau have retreated an average $6 \mathrm{~m} \mathrm{a}^{-1}$ over the 20th century (Zheng and Shi, 1975; Zheng, 1982; Ren and others, 1998, 2003; Su and Pu, 1998; $\mathrm{Pu}$ and others, 2004), and glaciers in the Qilian Shan on the northern margin of the plateau have also retreated since the 1970s (Wang and Liu, 1983; Xie and others, 1985; Wang, 1993; Shen and others, 2001; Liu and others, 2002). This distinct glacial change has commonly been attributed to the recent climatic warming in the study areas, which may have raised the snowline elevations (Yao and others, 1995, 1996; Wang and Yao, 2003; Yang and Yao, 2004). However, the specific processes that impact individual glaciers require further investigation. For example, Zhang and others (2004) linked water resources to the accumulation histories of individual glaciers, and concluded that the regional glacier changes are closely associated with the summer monsoon indices on the Asian continent.

The Chongce ice cap $\left(35^{\circ} 14^{\prime} \mathrm{N}, 81^{\circ} 07^{\prime} \mathrm{E}\right)$, located in the west Kunlun Shan along the southern margin of the Taklimakan desert (Fig. 1), was cored in 1992. This glacier has provided a variety of records of climatic and environmental change in this arid region. This paper focuses on the relationship between two of these records, atmospheric dust content and the snow accumulation.

\section{ICE PHYSICS AND ANALYTICAL METHODS}

The Chongce ice cap extends over a distance of about $7 \mathrm{~km}$, and contains two prominent domes at 6530 and $6374 \mathrm{~m}$ a.s.l. The ice core, which is $18.7 \mathrm{~m}$ long, or $\sim 40 \%$ of the total ice thickness, was drilled on the higher dome, the summit of which is presumably situated on an ice divide. In situ temperature measurements in an adjacent borehole that reached bedrock showed that at 15 m.b.s. (meters below surface) the ice was $-17.5^{\circ} \mathrm{C}$, while at the ice/rock interface it was $-17.1^{\circ} \mathrm{C}$, indicating favorable conditions for preserving the climatic and environmental records.

Core segments $(0.3-0.5 \mathrm{~m}$ long) were packed and sealed in polyethylene tubes, and stored in a cold room at $-20^{\circ} \mathrm{C}$ until the samples were prepared for analysis. After densities were determined for each of the segments, $2-5 \mathrm{~cm}$ thick samples were cut. The outer layers of the samples were cut away and analyzed for oxygen isotopic ratios $\left(\delta^{18} \mathrm{O}\right)$ using a Finnigan MAT mass spectrometer. The remaining interior portions were analyzed for major anions $\left(\mathrm{NO}_{3}{ }^{-}, \mathrm{SO}_{4}{ }^{2-}, \mathrm{Cl}^{-}\right)$ using a Dionex-100 ion chromatograph, and for cations $\left(\mathrm{Ca}^{2+}, \mathrm{Mg}^{2+}, \mathrm{K}^{+}, \mathrm{Na}^{+}\right)$using a Seiko SAS 7500 atomic absorption spectrophotometer equipped with a flame atomizer. These samples were measured for $\mathrm{pH}$ using a TOA FAR$101 \mathrm{pH}$ meter. Microparticle analyses were performed with a 


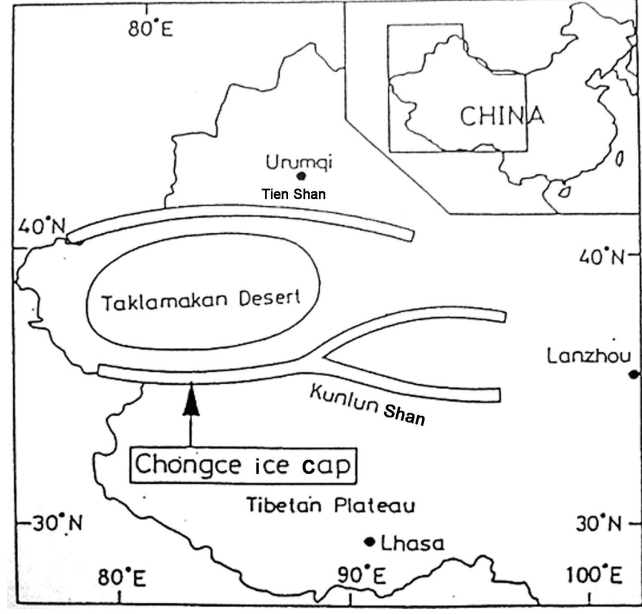

Fig. 1. Map showing the location of the Chongce ice cap in China.

Coulter Counter Multisizer, which, when equipped with a $30 \mu \mathrm{m}$ aperture tube, counts particles from 0.66 to $21.4 \mu \mathrm{m}$ in 32 size ranges. The residual melt from each of the samples was collected, and some samples were combined, to meet the volume requirement of $\sim 50 \mathrm{~mL}$ for individual tritium $\left({ }^{3} \mathrm{H}\right)$ measurements. These were analyzed by direct beta $(\beta)$ measurements in a liquid-scintillation spectrometer.

\section{CORE DATING AND DETERMINATION OF SNOW AND DUST DEPOSITION RATE}

Snow erosion by strong winds observed at the summit is thought to be the dominant cause of the very low accumulation at this site. Bamboo stake measurements from 26 August 1987 to 4 October 1992 show that over nearly 5 years the net snow accumulation totaled $93.6 \mathrm{~cm}$, for an annual average of $18.7 \mathrm{~cm}$ of snow, or $7.3 \mathrm{~cm}$ w.e., which translates to $73 \mathrm{~kg} \mathrm{~m}^{-2} \mathrm{a}^{-1}$. This value is much lower than the average of $200-500 \mathrm{~kg} \mathrm{~m}^{-2} \mathrm{a}^{-1}$ for the whole glacier (Nakawo and others, 1994), and even smaller than the minimum criterion of about $200 \mathrm{~kg} \mathrm{~m}^{-2} \mathrm{a}^{-1}$ for efficient application of $\delta^{18} \mathrm{O}$ to the establishment of chronology through seasonal variations (Dansgaard and others, 1973). Fortunately, since the glacier is composed of 'clean ice' without any visible dust layers, this insures that less 'noise' in the dust signal was introduced from local sources. In addition, the dominant size fraction of the dust particles is $<10 \mu \mathrm{m}$, which is similar to that of polar ice sheets. This allows us to attempt to date the core based on seasonal variations in microparticle concentrations, as was done successfully for some polar glaciers (Hammer, 1989). The sharp seasonal variation of airborne dust in western China, which is evident from dust loading from mid-February to late May with a strong maximum in late April to early May (Merrill and others, 1989), is manifested in the dust record of the Chongce ice core. Measurements of particle concentrations in the 0.66$1.33 \mu \mathrm{m}$ size range, in association with the variation of the chemically related ionic component $\mathrm{Ca}^{2+}$, were used to construct the chronology. The dating was calibrated by the presence of the prominent ${ }^{3} \mathrm{H}$ reference horizon produced by the nuclear weapons test in 1962-63; thus the uncertainty in the timescale is reduced to within 1 year, or about $1 \%$ of the ice-core length. The reconstructed timescale extends back to $~ 90$ years before 1992 (Fig. 2). An
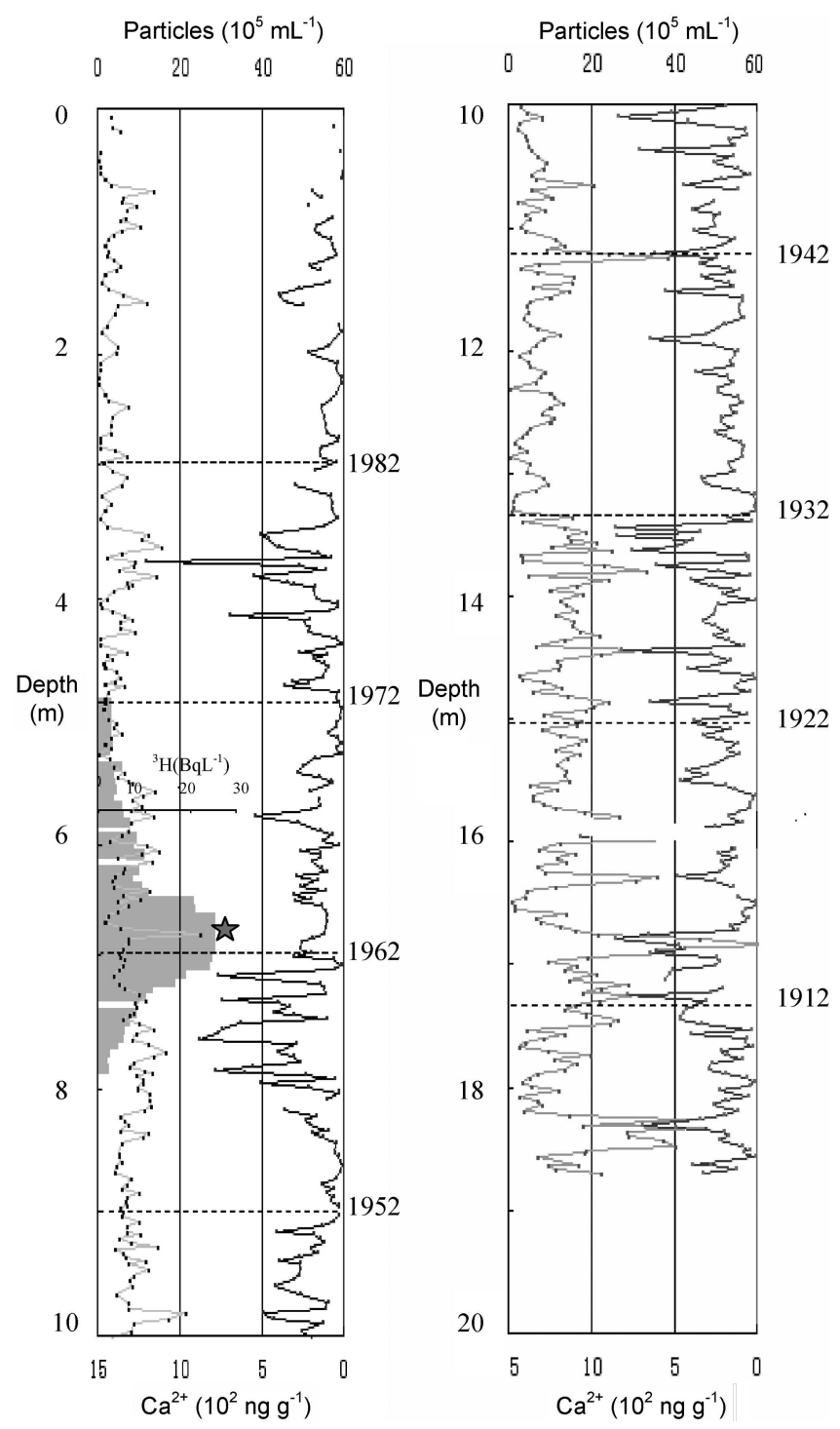

Fig. 2. (a) Records of microparticles ranging in size from 0.66 to $1.33 \mu \mathrm{m}$ (left) and $\mathrm{Ca}^{2+}$ concentration in $\mathrm{ngg}^{-1}$ (right) vs ice-core depth. Every 10 years is marked (dotted lines), and the 1963 nucleartest reference horizon is noted with a star. ${ }^{3} \mathrm{H}$ measurements (in $\mathrm{Bq} \mathrm{L}^{-1}$ ) between 5 and $8 \mathrm{~m}$.b.s. are illustrated by shaded bars.

extended description of these methods can be found in Han and Nakawo (2005).

The density calculations were multiplied by their respective layer thicknesses to reconstruct the annual net snow accumulation. The total particle weight concentration $(W)$ for each sample, in $\mathrm{mg} \mathrm{kg}^{-1}$, is determined by:

$$
W=\frac{N \rho 4 \pi\left(\frac{D_{1}+D_{2}}{4}\right)^{3}}{3},
$$

where $N$ is the particle concentration per $\mathrm{mL}$ of sample, $D_{1}$ and $D_{2}$ are the diameters (in $\mu \mathrm{m}$ ) of the particles in duplicate measurements of each sample (assuming that the particles are spherical) and $\rho$ is the average density of the dust, which is assumed to be $2 \mathrm{~g} \mathrm{~cm}^{-3}$ (Wagenbach and Geis, 1989). The dust deposition rate $(\lambda)$ is obtained by summing the weights of all the samples in an annual layer:

$$
\lambda=\sum W_{i} h_{i}
$$

where $i$ denotes the $i$ th sample in the annual layer and $h_{i}$ denotes the corresponding thickness. 


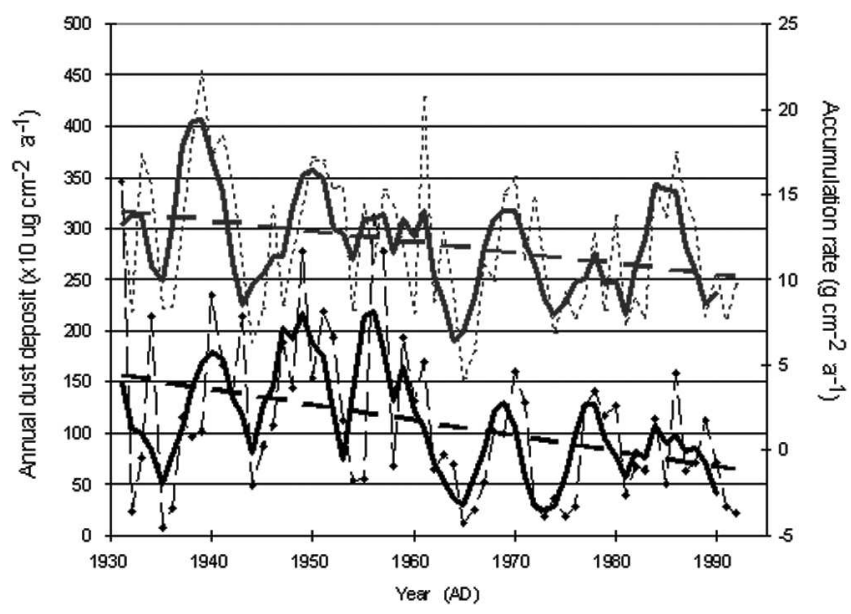

Fig. 3. Variations of annual dust deposition (lower curve) and snow accumulation rate (upper curve) between 1930 and the early 1990s recorded in the Chongce ice core. The solid lines represent 3 year smoothing averages, while dashed lines denote the linear trends.

\section{OVERALL DECREASING TRENDS IN SNOW AND DUST DEPOSITION}

The temporal sequence of dust deposition rate (in $\mu \mathrm{c} \mathrm{cm}^{-2} \mathrm{a}^{-1}$ ), along with the snow accumulation rate, for the past 60 years is plotted in Figure 3. Although the time series developed for the core extends back to 1903, the data from 13 to 18.7 m.b.s., corresponding to the interval 1903-32, were not included in this figure because the microparticle analyses were incomplete. The similarly decreasing trend in the two profiles is noticeable. Since the main features of snow redistribution in a glacier by wind are constant with time at a given location (Lliboutry, 1974), the relative changes in the annual snow/ice layer thickness calculated for the past 60 years should be significant for the precipitation trend. This should be true even though the values for snow accumulation rate should be regarded as a lower limit, since the effects of erosion result in the net accumulation being smaller than the actual precipitation.

In light of the similar trends of dust deposition rate and accumulation on the Chongce ice cap over these six decades, the following points deserve further investigation:

1. Among all the various aerosols such as $\mathrm{SO}_{4}{ }^{2-}$, what processes allow dust particles (despite their nonhygroscopic character) to act as cloud condensation nuclei $(\mathrm{CCN})$, which affects precipitation at high altitudes?

2. What processes allow dust aerosols to serve as the principal factor controlling the precipitation at high altitudes, which over recent decades has shown a decreasing trend at the same time that the precipitation rate at the lower elevations around the Taklimakan desert has been increasing (Zhang and others, 2004)?

3. Assuming that the persistently decreasing dust content in the sink area has a close relationship to that in the source region, is there evidence for linkages from source to sink areas in terms of dust formation, transportation and deposition processes?

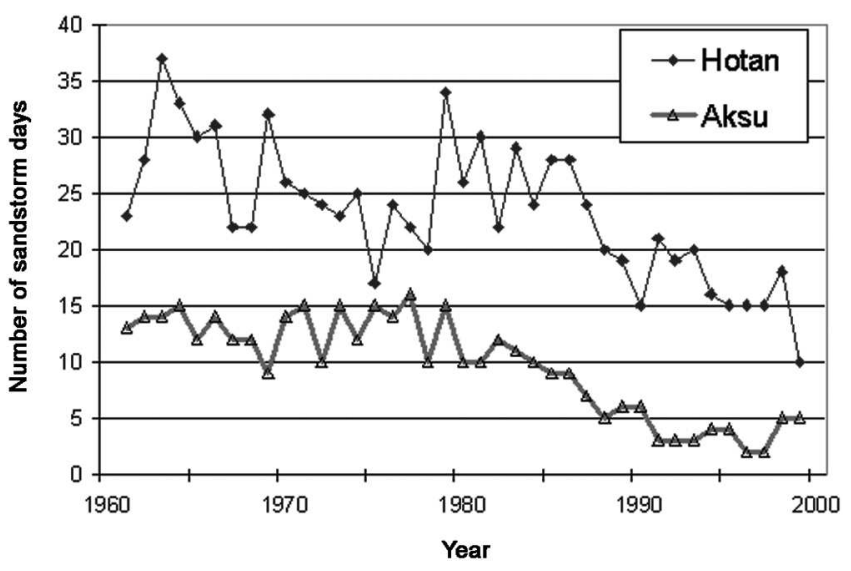

Fig. 4. Sandstorm days per year in Hotan and Aksu, 1960-2000. This figure first appeared in Wang and others (2003).

\section{DUST TRENDS AROUND THE TAKLIMAKAN DESERT}

Until the 1950s, there existed no systematic meteorological observation network around the Taklimakan desert. Since then such a network, consisting of more than 30 stations, has been established and measurements of three types of atmospheric processes conducive to the dispersion of atmospheric dust, i.e. dust storm, blowing sand and floating dust (Li, 1991), have been logged. These observations indicate an overall decline of dust events in any of these forms over the last four to five decades (He and others, 2003). Variability in such trends is typically represented by the sandstorm days per annum, which are characterized by extraordinarily strong gales with wind speeds $>20 \mathrm{~m} \mathrm{~s}^{-1}$ that lift tremendous amounts of soil-mineral particulates into the air, reducing visibility to $<1 \mathrm{~km}$ in places such as Hotan and Aksu (Fig. 4). The Chongce ice-core records reflect this tendency over the same time-span (Fig. 3). Such changes were partially attributed to the weakening of prevailing winds around the deserts in southern Xinjiang Province. The incidence of sandstorms at more than ten observed stations dropped from 136 in the 1960s to 33 in the 1990s (Cui, 2000), and the average maximum wind speed diminished from $9.32 \mathrm{~m} \mathrm{~s}^{-1}$ in the decade $1960-70$ to $6.88 \mathrm{~m} \mathrm{~s}^{-1}$ in the decade 1980-90 (Shi, 2003).

Over the same period the vegetation cover in the surrounding region appeared to increase. The normalized differential vegetation index (NDVI) shows that, since the 1980s, vegetation has spread over several representative sites including Hotan (Ma and others, 2003). This growing ground cover efficiently hinders desertification, thus mitigating severe soil erosion. The driving force behind the vegetation growth in these inland arid regions is the increasingly humid climate during recent decades. Yu and others (2003) noted an increase in the vapor content of the atmosphere in northwestern China since the 1980s. One of the two centers of increasing precipitation is located in the Tarim basin, where the Taklimakan desert is located. Over the last 40 years, annual precipitation has increased $>30 \%$ (Shi, 2003) and discharge from high mountain rivers has also increased significantly (Zhang and others, 2003).

It seems that conditions are unfavorable for dust sources to increasingly supply suspended material in the air over this time. It is also apparent that atmospheric dust tends to be removed by scavenging by the increasing water-vapor 


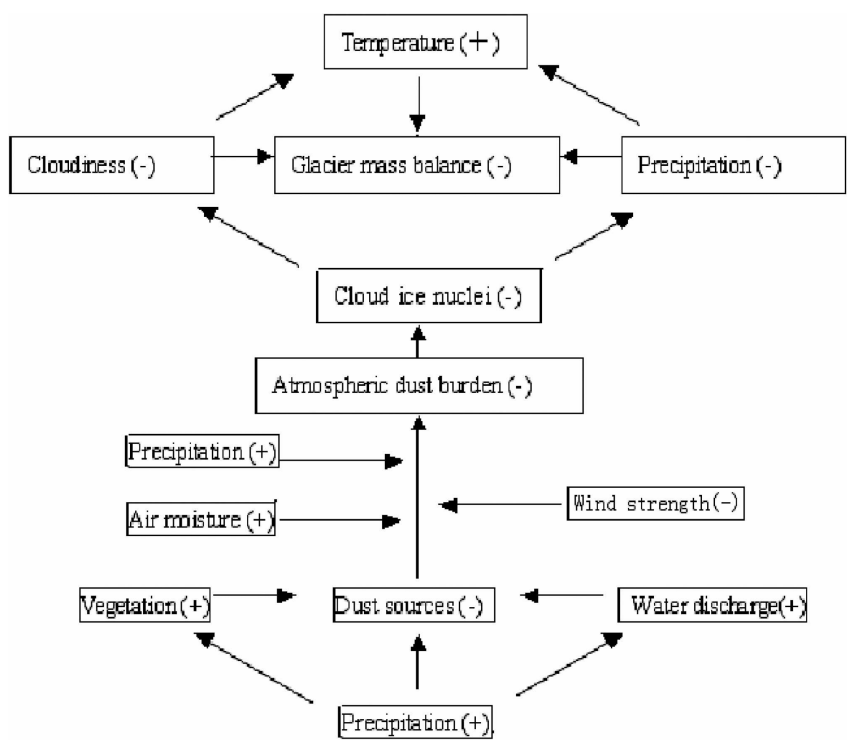

Fig. 5. Diagram of variables related to the dust processes and their inherent connections to the mass-balance changes of high mountain glaciers under increasingly wet climate conditions over the inland arid region.

condensation, resulting in decreasing dust burden in the middle atmosphere. The major factors acting on airborne dust and their inherent effects on each other in the middle troposphere are illustrated in Figure 5.

Air-circulation patterns over the Tarim basin during the main dust season have been investigated extensively. In the spring, the air from surrounding high mountains descends into the basin. The late-winter northerlies and northwesterlies above 500 mbar persist across the north of the desert, then travel around to the east site of the Tien Shan (Fig. 1). Locally named the Kara Bran (or 'black wind'), this wind is much stronger than airflow from other routes and carries a tremendous amount of dust from the desert. The dust moves upward due to convergence and then moves southwards. In this way, the entrained fine size fraction can be carried to the middle or even upper troposphere (Geng, 1985; Zhao, 1985). Such source-sink relationships strongly confirm the suggestion that the dust trend found in the Chongce ice-core record is indicative of decadal dust trends occurring around the Taklimakan desert.

\section{DUST EFFECTS ON PRECIPITATION-FORMING PROCESSES AT HIGH ELEVATION}

When aerosol particulates act as cloud condensation nuclei (CCN), both their chemical properties and their size ranges are critical (Junge, 1977). Hygroscopic particles may become centers of growth for water droplets as the supersaturation reaches a critical threshold. However, when temperatures become sufficiently cold during transport, the cloud ice nuclei (CIN) may become activated. Unlike condensation nuclei, these consist of non-hygroscopic particles with crystal lattice structures and shapes conducive to ice formation. Therefore, aerosols derived from crust erosion generally make good ice nuclei (Kumai, 1968; Pruppacher and Klett, 1978). Clouds can contain liquid droplets at temperature down to $-30^{\circ} \mathrm{C}$, known as supercooled water (Davidson, 1989). This combination of microscopic particles and cloud formation in cold regions is most efficiently achieved with particulates in the submicron to micron size range, typically $0.1-2 \mu \mathrm{m}$ in radius.

High altitudes where glaciers form provide temperatures below $0^{\circ} \mathrm{C}$ for the annual average at the equilibrium line, but also provide a good environment for CIN from dust aerosols to form. In the case of the west Kunlun Shan, the dust that originates from the Taklimakan desert undergoes size sorting during entrainment before traveling over several thousand meters, and only particles $<10 \mu \mathrm{m}$ in diameter remain in suspension over such distances. In the Chongce ice-core record, $>75 \%$ of the dust population is composed of particles with radii $<2 \mu \mathrm{m}$. This combination of low temperatures and fine-dust availability allows the available airborne particles to act as $\mathrm{CIN}$ in preference to other aerosols such as $\mathrm{SO}_{4}{ }^{2-}$, and to play a dominant role in the precipitation-making process. It also leads to the effective wet deposition of the dust itself (Han and others, 2005). This could serve as an explanation for the similar variability of the accumulation and dust concentration profiles that are illustrated in Figure 3.

In addition, the CIN of dust aerosols plays an indirect role in glacier dynamics. A $30 \%$ decrease in cloudiness is equivalent to a $25 \%$ decrease in precipitation in a glacial area, and has the same effect on glacier retreat as a temperature increase of $1{ }^{\circ} \mathrm{C}$ (Houghton and others, 2001). Decreases in $\mathrm{CIN}$ might therefore contribute to negative influences on glacier mass balance, resulting in glacial ablation in the long run (Fig. 5, top half).

\section{CONCLUSIONS}

The above argument regarding the importance of CIN to precipitation might apply differently for individual glaciers. In the case of Ürümqi glacier No. 1, with a snowline altitude of $4000 \mathrm{~m}$, the dust concentration is high because of the low relief between the glacier and the Taklimakan desert. However, the airborne dust burden decreases with increasing elevation. Here, as long as temperatures become low enough for $\mathrm{CIN}$ processes to be activated, the vapor supply must be the primary determinant of precipitation. As it is located in an area where precipitation is increasing, the primary cause for the retreat of Ürümqi glacier No. 1 is most likely the temperature increase over recent decades (Jiao and others, 2004). The Chongce ice cap provides an example of how dust aerosols play a dominant role in the precipitation processes independently of the moisture supply. It demonstrates that mountain glaciers above a certain elevation seem to be more sensitive than lowerelevation glaciers to the air-burden dust particulates and their effects on snow accumulation. As the dust population available for $\mathrm{CIN}$ at these altitudes is not as great as at the lower elevations, change in the population must directly influence the precipitation regime. The present trends of both accumulation and dust concentration observed in the core are closely associated with the climatic trends in the inland arid region; the coherent decreases might continue provided the current climate trend surrounding the desert persists.

The environmental record from the Chongce ice cap provides a time series of the dust burden for the Taklimakan desert region, but it can only be taken as an individual case, because any particular ice-core record could be tied closely to the deposition process of its glacier, or even that of its own drilling site. For example, opposite trends between snow 
accumulation and dust concentration have been reported from Guliya glacier (Yao and others, 1995), which is also located in the west Kunlun Shan. In another case, snow accumulation has decreased while dust has increased over the past 100 years in Dasuopu glacier (7200 ma.s.I.) in the Himalaya (Thompson and others, 2000). Additional research on the relationship of both moisture and dust to the precipitation in association with the regional climatic patterns should help to explain the complicated atmospheric processes affecting the glacial mass balance at high altitudes.

\section{ACKNOWLEDGEMENTS}

We are indebted to all of the members of the field expedition. We also thank $\mathrm{H}$. Kanda for generous assistance with the laboratory analysis. We gratefully acknowledge the contribution of the 'Aeolian Dust Experiment on Climate Impact', the Special Coordination Funds for the Promotion of Science and Technology, Japan (No. 62041043 and No. 63043030). We thank the reviewers for valuable comments and suggestions, and M. Davis for correcting the English.

\section{REFERENCES}

Cui, C.X. 2000. Analysis of climate and sandstorms in Xinjiang in recent 40 years. Meteorology, 27(12), 38-41. [In Chinese with English summary.]

Dansgaard, W., S.J. Johnsen, H.B. Clausen and N. Gundestrup. 1973. Stable isotope glaciology. Medd. Grønl., 197(2), 1-53.

Davidson, C.I. 1989. Mechanisms of wet and dry deposition of atmospheric contaminants to snow surfaces. In Oeschger, $\mathrm{H}$. and C.C. Langway, Jr, eds. The environmental record in glaciers and ice sheets. Chichester, etc., John Wiley and Sons, 29-51.

Geng, K.H. 1985. Features of eolian climate in the arid lands in China. In Zhao, S.Q., ed. Physical geography of China's arid lands. Beijing, Science Publications. [In Chinese with English summary.]

Hammer, C.U. 1989. Dating by physical and chemical seasonal variations and reference horizons. In Oeschger, $\mathrm{H}$. and C.C. Langway, Jr, eds. The environmental record in glaciers and ice sheets. Chichester, etc., John Wiley and Sons, 99-121.

Han, J.K. and M. Nakawo. 2005. Ice core record in an Asian glacier at $6530 \mathrm{~m}$ a.s.l.: overall declination of atmospheric dust flux for past 60 a. In Proceedings of Fourth ADEC Workshop - Aeolian Dust Experiment on Climate Impact, 313-316.

He, Q., Q. Yang and H.J. Li. 2003. Variations of air temperature, precipitation and sand-dust weather in Xinjiang in past 40 years. J. Glaciol. Geocryol., 25(2), 425-427. [In Chinese with English summary.]

Houghton, J.T. and 7 others. 2001. Climate change 2001: the scientific basis. Contribution of Working Group I to the Third Assessment Report of the Intergovernmental Panel on Climate Change. Cambridge, etc., Cambridge University Press.

Jiao, K., S.F. Jing and T.D. Han. 2004. Variation of the Glacier No. 1 at the headwaters of the Ürümqi River in the Tien Shan Mountains during the past 42 years and its trend prediction. J. Glaciol. Geocryol., 26(3), 253-260. [In Chinese with English summary.]

Junge, C.E. 1977. Processes responsible for the trace content in precipitation. IAHS Publ. 118 (Symposium at Grenoble 1975 Isotopes and Impurities in Snow and Ice), 63-76.

Kumai, M. 1968. Fog modification on the Greenland ice cap. In Proceedings of the First National Conference on Weather Modification. Albany, NY, American Meteorological Society, 414-422.
Li, J.F. 1991. Climate of Xinjiang. Beijing, Meteorological Press. [In Chinese.]

Liu, S., Y.P. Shen and W.X. Sun. 2002. Glacier variation since the maximum of the Little Ice Age in the western Qilian Mountains, northwest China. J. Glaciol. Geocryol., 24(3), 227-233. [In Chinese with English summary.]

Lliboutry, L. 1974. Multivariate statistical analysis of glacier annual balances. J. Glaciol., 13(69), 371-392.

Ma, M.G., L.X. Dong and X.M. Wang. 2003. Study on the dynamically monitoring and simulating the vegetation cover in northwest China in the past 21 years. J. Glaciol. Geocryol., 25(2), 252-256. [In Chinese with English summary.]

Merrill, J.T., M. Uematsu and R. Bleck. 1989. Meteorological analysis of long range transport of mineral aerosols over the north Pacific. J. Geophys. Res., 94(D6), 8584-8598.

Nakawo, M., K. Goto-Azuma and J.K. Han. 1994. Decreasing trend of precipitation in the last 30 years at a mountain site near the Taklamakan Desert, western China. Riken Rev. 5, 11-12.

Pruppacher, H.R. and J.D. Klett. 1978. Microphysics of clouds and precipitation. Dordrecht, Reidel Publishing Company.

Pu, J.C., T.D. Yao, N.L. Wang, Z. Su and Y. Shen. 2004. Fluctuations of the glaciers on the Qinghai-Tibetan Plateau during the past century. J. Glaciol. Geocryol., 26(5), 517-522. [In Chinese with English summary.]

Ren, J.W., D.H. Qin and Z.F. Zing. 1998. Climatic warming make the glaciers retreating in Mt Everest region. J. Glaciol. Geocryol., 20(5), 17-18. [In Chinese with English summary.]

Ren, J.W., D.H. Qin and S.C. Kang. 2003. Glaciers variation and character of climatic warming and drying in central region of Himalayas. Chinese Sci. Bull., 48(23), 2478-2482.

Shen, Y.P., S.Y. Liu, G. Wang and G.X. Liu. 2001. Fluctuations of glacier mass balance in watersheds of Qilian Mountains and their impact on water resources of Hexi region. J. Glaciol. Geocryol., 23(3), 244-250. [In Chinese with English summary.]

Shi, Y.F. 2003. An assessment of the issues of climatic shift from warm-dry to warm-wet in northwest China. Beijing, Meteorological Press.

Su, Z. and J.C. Pu. 1998. Contemporary climatic variation over Qinghai-Xizang (Tibetan) Plateau and their influence on environments. Guangzhou, Guangdong Science and Technology Press.

Thompson, L.G., T. Yao, E. Mosley-Thompson, M.E. Davis, K.A. Henderson and P. Lin. 2000. A high-resolution millennial record of the south Asian monsoon from Himalayan ice cores. Science, 289(5486), 1916-1919.

Wagenbach, D. and K. Geis. 1989. The mineral dust record in a high altitude Alpine glacier (Colle Gnifetti, Swiss Alps). In Leinen, M. and M. Sarnthein, eds. Paleoclimatology and paleometeorology: modern and past patterns of global atmospheric transport. Dordrecht, etc., Kluwer Academic Publishers, 543-564. (NATO ASI Series C: Mathematical and Physical Sciences 282.)

Wang, N.L. and T.D. Yao. 2003. Contribution of ice core to the past global change research. J. Glaciol. Geocryol., 25(3), 275-287. [In Chinese with English summary.]

Wang, X., Y. Ma, H.W. Chen and P. Zhang. 2003. Analysis on the climatic characteristics of sandstorms in south Xinjiang. J. Desert Res., 23(2), 123-144. [In Chinese with English summary.]

Wang, Z.T. and C.H. Liu. 1983. Development conditions and distribution features and regional divisions of present glaciers in Qilian Mountains. Acta Geogr. Sin., 38(2), 141-153. [In Chinese with English summary.]

Wang, Z.T. 1993. The glacier variation and influence since Little Ice Age and future trends in northwest region, China. Sci. Geogr. Sin., 13(2), 97-103.

Xie, Z., G. Wu and L. Wang. 1985. Recent advance and retreat of glaciers in Qilian Shan. Mem. Lanzhou Inst. Glaciol. Cryopedol. Academica Sinica 5, 82-90. [In Chinese.]

Yang, M.X. and T.D. Yao. 2004. Ice core records in the past 2000 years and climate warming during the 18th-20th centuries. J. Glaciol. Geocryol., 26(3), 290-293. 
Yao, T.D., K.Q. Jiao, Z.H. Yang and others. 1995. The climate changes since the Little Ice Age in the Guliya ice core. Sci. China B, 25(10), 1108-1114.

Yao, T.D., D.H. Qin and L.D. Tian. 1996. The variations of the temperature and precipitation in the past 2000 years in Tibetan Plateau-Guliya ice core records. Sci. China D, 26(4), 348-353.

Yu, Y.X., J.S. Wang and Q.Y. Li. 2003. Spatial and temporal distribution of water vapor and its variation trend in atmosphere over northwest China. J. Glaciol. Geocryol., 25(2), 149-156. [In Chinese with English summary.]

Zhang, G.W., S.F. Wu and Z.J. Wang. 2003. Reaction for signal of climatic shift from warm-dry to warm-humid in northwest China in variation of river run-off in Xinjiang. J. Glaciol. Geocryol., 25(2), 183-187.
Zhang, Z.L., Y.Q. He, H.X. Pang and others. 2004. Accumulation and moisture sources of the glaciers in China. J. Glaciol. Geocryol., 26(6), 729-735. [In Chinese with English summary.] Zhao, S.Q. 1985. The sandy deserts and the Gobi in China: their origin and evolution. In Zhao, S.Q., ed. Physical geography of China's arid lands. Beijing, Science Publications, 1-17.

Zheng, B.X. 1982. Characteristics on the post-glacial advance and retreat in Mount Xixabangma region. In Report on Mount Xixabangma Scientific Expedition 1964. Beijing, Science Press, 177-191.

Zheng, B.X. and Y.F. Shi. 1975. Variation of glaciers in Mt Qomolangma. In Report of scientific expedition in Mt Qomolangma (1966-1968): glaciology and geomorphology. Beijing, Science Press, 92-105. [In Chinese.] 